Article

\title{
Adsorption and Desorption of Cd by Soil Amendment: Mechanisms and Environmental Implications in Field-Soil Remediation
}

\author{
Shanshan $\mathrm{Li}^{1}$, Meng Wang ${ }^{2, *}(\mathbb{D})$, Zhongqiu Zhao ${ }^{1}$, Changbao $\mathrm{Ma}^{3}$ and Shibao Chen ${ }^{2, *}$ \\ 1 School of Land Science and Technology, China University of Geosciences, Beijing 100083, China; \\ 1ss117@163.com (S.L.); zhongqiuzhao@163.com (Z.Z.) \\ 2 Key Laboratory of Plant Nutrition and Fertilizer, Ministry of Agriculture/Institute of Agricultural Resources \\ and Regional Planning, Chinese Academy of Agricultural Sciences, Beijing 100081, China \\ 3 Cultivated Land Quality Monitoring and Protection Center, Ministry of Agriculture, Beijing 100125, China; \\ macb@agri.gov.cn \\ * Correspondence: wangmeng@caas.cn (M.W.); chenshibao@caas.cn (S.C.); \\ Tel.: +86-010-8210-6722 (M.W. \& S.C.)
}

Received: 7 June 2018; Accepted: 3 July 2018; Published: 5 July 2018

\begin{abstract}
In China, 1/5 of the total farmland area is Cd-enriched; the wide occurrence of Cd-contaminated soil in China has already posed significant public health risk and deserves immediate action. In situ immobilization has been regarded as one of the most promising agricultural extension-technologies for remediating low-to-medium levels of heavy metal contaminated land in China. Although extensive research has been conducted to examine the effectiveness of different amendments on remediation of $\mathrm{Cd}$-contaminated soils, the influence of changed soil properties on secondary release of $\mathrm{Cd}$ from $\mathrm{Cd}$-amendment to soil is rarely known. The objective of this study was to evaluate the effectiveness of four soil amendments (denoted as Ad1, Ad2, Ad3 and Ad4, their main components being clay mineral, base mineral, humus and biochar, respectively) on reducing $\mathrm{Cd}$ availability and increasing $\mathrm{Cd}$ stability in soil. The maximum adsorption capacity of test amendments on $\mathrm{Cd}$ ranged from 7.47 to $17.67 \mathrm{mg} \mathrm{g}^{-1}$. The characterizations of test amendments before and after $\mathrm{Cd}$ loading provided the evidence that surface precipitation and ion exchange were the main reasons for Ad1 and Ad2 to adsorb Cd, and complexation was for Ad3 and Ad4. In addition, there was significant increase in the desorption percentages of $\mathrm{Cd}$ from amendments as $\mathrm{pH}$ decreased (from 7 to 1) or ion strength increased (from 0 to $0.2 \mathrm{M}$ ). Comparatively, $\mathrm{Ad} 3$ and Ad4 could be more effective for in situ immobilization of $\mathrm{Cd}$ in contaminated soils, due to their high adsorption capacities (12.82 and $17.67 \mathrm{mg} \mathrm{g}^{-1}$, respectively) and low desorption percentages (4.46-6.23\%) at $\mathrm{pH}$ from 5 to 7 and ion strengths from 0.01 to $0.1 \mathrm{~mol} \mathrm{~L}^{-1}$. The results obtained in this study could provide a guideline for in-situ remediation of $\mathrm{Cd}$ polluted field-soil in China.
\end{abstract}

Keywords: soil amendments; Cd(II); adsorption; desorption; environmental implications

\section{Introduction}

Soil heavy metal contamination is regarded as one of the most severe environmental issues globally due to its elusive invisibility, persistence and irreversibility, as well as high-toxicity [1-5]. In China, more than 100 million ha of land are contaminated by heavy metal, and, among all inorganic pollutants, the over-standard rate of $\mathrm{Cd}$ is up to $7.0 \%$ [2,3]. More than 11 provinces and 25 districts of China are subjected to Cd-enriched soil [4,5]. Cd is considered as one of the most toxic metals in plants due to its high water solubility and phytotoxicity. Generally, $\mathrm{Cd}$ is released into the soil environment through various industrial processes (e.g., metal smelting, coal or oil burning, wood combustion, and waste 
incineration) and agricultural activities (including the use of $P$ fertilizers, the disposal of sewage sludges and mine tailings or the irrigation of wastewaters) [6]. After its import into agro-ecosystems, it affects not only the agricultural environment quality, but also the yield and safety of rice, vegetables and fish, and it threatens the health of animals and humans through the food chain [7-10]. High exposure to $\mathrm{Cd}$ has adverse effects to human health, causing lung diseases, nephropathy, prostate diseases, etc. [11]. Particularly, a total of 13,300 ha arable land in China was found to be polluted with Cd, leading to a decline of 1000 tons crop yield every year, resulting in potential pollution of grains and a high health risk $[12,13]$.

Current remediation methods of $\mathrm{Cd}$ contaminated soils can be divided into two types, mobilization and immobilization. The basic principle related to the mobilization techniques is to release $\mathrm{Cd}$ into soil solution, which is subsequently removed by plants, leaching, electrokinetic strategies, etc. [6]. In contrast, immobilization of $\mathrm{Cd}$ into soil can be achieved mainly through chemical reactions such as adsorption, precipitation, and complexation, leading to the redistribution of $\mathrm{Cd}$ from solution phase to solid phase [14]. Generally, methods of leaching and electromigration are restricted by not only the high cost, but also the low effectiveness [15]. Plant uptake of Cd from soils is more economical, but it could delay the period of crop planting [16]. Therefore, stabilization (immobilization) of $\mathrm{Cd}$ in its contaminated soils are widely applied. They refer to the use of in-situ techniques that could reduce the bioavailability of $\mathrm{Cd}$ in soils by utilizing immobilization agents or amendments [17]. Many natural minerals and organic compounds, agricultural wastes and industrial wastes are used as absorbents. These absorbents can increase cation exchange capacities, intensify microbiological activities, improve physical properties and improve soil fertility; therefore, they have traditionally been regarded as sources of soil nutrients [18]. The advantages of sorbents are that they appear to be economically attractive due to their low-cost and broad existence, and they can be operated under a broad range of conditions ( $\mathrm{pH}$ and soil types) [19]. Therefore, it is not necessary to remove heavy metal from soils to control or manage its risks on crop growth or human health. Metal inactivation by reducing metal availability and maximizing metal stability can display a high potential in in situ soil remediation on industrial, smelting, and mining sites, and particularly on agricultural lands during remediation.

Recently, more efforts are being made to apply soil amendments including phosphate compounds, clays, minerals, composts, metal oxides, biochar, humus, etc. for in-situ field-scale remediation of Cd contaminated soil [20-25]. For example, the application of biochar $\left(40 \mathrm{t} \mathrm{ha}^{-1}\right)$ resulted in a $52.5 \%$ decrease in the concentration of soil $\mathrm{CaCl}_{2}$ extractable $\mathrm{Cd}$ and a $54.2 \%$ decrease in total plant uptake of $\mathrm{Cd}$, compared with those without biochar [26]. There is also report on the remediation of Cd-contaminated soil by clay minerals. Liang et al. [27] found that adding attapulgite could increase soil $\mathrm{pH}$ and significantly reduce the concentration of soil extractable $\mathrm{Cd}$, resulting in a remarkable reduction in Cd accumulation into brown rice. Similarly, when $15 \%$ of natural zeolite was applied to remediate Cd-contaminated soil, more than $65 \%$ of $\mathrm{Cd}$ was stabilized [28]. Although broad attention has been paid on utilizing agents or amendments to immobilize $\mathrm{Cd}$, their stability after immobilization needs to be well specified, especially when their long-term application in field-soil remediation is considered [4,29]. Therefore, it is well recognized that the criteria of an effective soil amendment should include the reduction of Cd availability and the increase of $\mathrm{Cd}$ stability in polluted soil.

Although numerous researchers have paid close attention to the effectiveness of different amendments on remediation of $\mathrm{Cd}$-contaminated soils, the influence of changed soil characteristics on secondary release of $\mathrm{Cd}$ from $\mathrm{Cd}$-amendment to soil is rarely reported. The objective of this study was to evaluate the effectiveness of soil amendments on stabilization of $\mathrm{Cd}$, through examining their sorption capacities and desorption percentages of $\mathrm{Cd}$. The effects of $\mathrm{pH}$ and ion strength on $\mathrm{Cd}$ desorption from amendment- $\mathrm{Cd}$ were studied over the $\mathrm{pH}$ range 1.0-7.0 at $\mathrm{NaNO}_{3}$ concentrations of $0.0-0.2 \mathrm{mg} \mathrm{L}^{-1}$. The associated mechanisms for $\mathrm{Cd}$ sorption and desorption in the presence of amendments were elucidated. Results obtained in this study would provide the reference for in situ remediation of cadmium contaminated farmland in China. 


\section{Materials and Methods}

\subsection{Materials and Chemicals}

Numerous natural mineral, organic compounds, and agricultural and industrial waste products, including phosphate compounds, clay minerals, organic composts, metal oxides, biochar, humus, etc., can be used as soil amendments. These amendments are traditionally considered as sources of soil nutrients because they have the ability to increase cation exchange capacities, intensify microbiological activities, and improve physical properties (e.g., structure and water holding capacity) and fertility of soils [30-32]. In this study, four different amendments were prepared and compared: Ad1 contained a mixture of attapulgite and triple superphosphate; Ad2 consisted of zeolite and triple superphosphate; Ad3 was prepared by blending hydroxyapatite and humus; and Ad4 was the rice hull biochar prepared by high temperature carbonization (up to $550^{\circ} \mathrm{C}$ ). More information about the amendment preparation and their characteristics has been described in detail in our previous paper [33]. All reagents were of analytical reagent grade and used as supplied from Sinopharm Chemical Reagent Ce. Lid. Stock solutions (1000 mg L ${ }^{-1}$ ) of Cd was prepared by direct dissolution of $\mathrm{CdCl}_{2}$ salts in deionized (DI) water. The $\mathrm{pH}$ values of the solutions were adjusted by dropwise addition of $0.01 \mathrm{M}$ of $\mathrm{HCl}$ and/or $0.01 \mathrm{M}$ of $\mathrm{NaOH}$. Similarly, the ion strength of the solutions was adjusted by $\mathrm{NaNO}_{3}$.

\subsection{Characterization of Amendments}

The soil amendments were firstly ground and then sieved through 300 mesh $(48 \mu \mathrm{m})$. The collected powder was blended with $\mathrm{CdCl}_{2}$ solution $(120 \mathrm{mg} / \mathrm{L})$ thoroughly and oscillated for $24 \mathrm{~h}$. It should be noted that the complexation of $\mathrm{Cl}^{-}$with $\mathrm{Cd}^{2+}$ to form the complex $\mathrm{CdCl}_{\mathrm{n}(2-n)}$ may increase $\mathrm{Cd}$ bioavailability. In on our previous test, we investigated the anion compositions of soil solution in 12 Chinese typical agricultural soils, and found that $\mathrm{Cl}^{-}$content in these soil solutions was in the range of 1.209-1.693 mol/L; therefore, in this study, to simulate the soil environments, the maximum

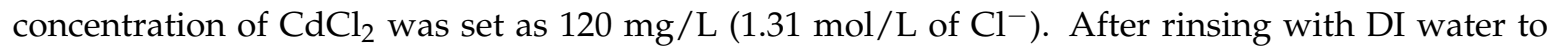
remove free $\mathrm{Cl}^{-}$, the samples were dried in a drying oven with a constant temperature of $50{ }^{\circ} \mathrm{C}$ for $24 \mathrm{~h}$. The amendments before and after loading $\mathrm{Cd}$ was characterized by particle size analyzer, surface area analyzer and X-ray diffractometer. Specifically, the mean grain size was analyzed using a laser particle analyzer (HORIBA LA-950, Horiba, Kyoto, Japan), the surface area was measured by single point Brunauer-Emmett-Teller (BET) $\mathrm{N}_{2}$ sorption procedure (BET- $\mathrm{N}_{2}$ : Quantachrome Instruments, Boynton Beach, FL, USA), and the identification of crystallinity and crystal phase of samples was performed by a Bruker D8 Advance X-ray diffractometer (Karlsruhe, Germany). Physical and chemical properties of these amendments were also tested by the methods similar to what was conducted for the $\mathrm{Cd}$ contaminated soil samples. Specifically, $\mathrm{pH}$ of a 1:2.5 $(w / w)$ amendment- $\mathrm{CaCl}_{2}$ water suspension was tested by a $\mathrm{pH}$ meter (Denver Instrument UB-7 pH/mV Meter, ultraBASIC). Cation exchanging capacity (CEC) was tested by the barium chloride method. The potassium dichromate outside heating method was used to determine soil organic matter. The $\mathrm{Cd}$ concentration in the amendments was measured by digesting about $0.2 \mathrm{~g}$ of amendments with $4.5 \mathrm{~mL} \mathrm{HCl}(37 \%), 1.5 \mathrm{~mL} \mathrm{HNO}_{3}(65 \%)$ and $1 \mathrm{~mL} \mathrm{H}_{2} \mathrm{O}_{2}(30 \%)$ in a Teflon bomb placed in a microwave digestion apparatus (Milestone MLS $1200 \mathrm{Mega})$. The $\mathrm{Cd}$ concentrations in the digests were determined using a PerkinElmer 1100B atomic absorption spectrometer. No cadmium was detected in the amendments used in our study. The basic physical and chemical properties of soil amendments are displayed in Table 1. 
Table 1. Basic physical and chemical properties of the soil amendments.

\begin{tabular}{|c|c|c|c|c|}
\hline \multirow{2}{*}{ Amendments } & $\mathrm{pH}$ & CEC & Organic & $\mathrm{Cd}$ \\
\hline & (water/Soil = 2.5:1) & $(\mathrm{cmol}+/ \mathrm{kg})$ & Carbon $\left(\mathrm{g} \mathrm{kg}^{-1}\right)$ & $\left(\mathrm{mg} \mathrm{kg}^{-1}\right)$ \\
\hline Ad1 & $7.95 \pm 0.06$ & $125.60 \pm 8.19$ & $58.62 \pm 3.12$ & ND \\
\hline Ad2 & $8.13 \pm 0.09$ & $210.30 \pm 10.23$ & $36.73 \pm 1.95$ & ND \\
\hline Ad3 & $7.92 \pm 0.04$ & $176.70 \pm 7.65$ & $420.21 \pm 23.14$ & ND \\
\hline $\mathrm{Ad} 4$ & $9.28 \pm 0.06$ & $115.10 \pm 1.88$ & $67.38 \pm 25.89$ & ND \\
\hline
\end{tabular}

Notes: ND means no cadmium detected in the amendments.

\subsection{Adsorption and Desorption Experiments}

Adsorption isotherm experiments were performed to determine the maximum adsorption capacity of $\mathrm{Cd}$ and a constant related to the binding energy of $\mathrm{Cd}$ based on each amendment. Adsorption study was conducted in a batch experiment: $30 \mathrm{~mL}$ aliquots of $0.05 \mathrm{~mol} \mathrm{~L}^{-1} \mathrm{NaNO}_{3}$ background electrolyte solution, including a known amount of $\mathrm{Cd}$ concentration ranging from 0 to $120 \mathrm{mg} \mathrm{L}^{-1}$ $\left(0,0.5,1,2,5,10,30,60,90\right.$, and $\left.120 \mathrm{mg} \mathrm{L}^{-1}\right)$ was equilibrated with $0.2 \mathrm{~g}$ of amendments in a $50 \mathrm{~mL}$ polycarbonate centrifuge tube. All tubes were instantly sealed and then mechanically oscillated on an over-to-over shaker $(\sim 50 \mathrm{r} / \mathrm{min})$ at normal temperature $\left(25 \pm 2{ }^{\circ} \mathrm{C}\right)$ for $24 \mathrm{~h}$ based on a preliminary experiment that observed no obvious adsorption after 24-h reaction. Centrifugation (at $5000 \mathrm{r} \mathrm{min}^{-1}$ for $30 \mathrm{~min}$ ) was used to separate the supernatant and solid residues, and then the supernatant was filtered through a $0.45 \mu \mathrm{m}$ membrane pore size filter, the collected filtrate was subjected to a PerkinElmer 1100B atomic absorption spectrometer for determination of Cd concentration. Each processing was set three repetitions.

Desorption experiments were conducted to demonstrate the stability of $\mathrm{Cd}$ on each amendment. Desorption was measured immediately after adsorption of $\mathrm{Cd}$ by amendments (in Section 2.3) at maximum concentration point (the stock solution of $\mathrm{Cd}$ at a concentration of $120 \mathrm{mg} \mathrm{L}^{-1}$ in the batch experiment). Specifically, the solid residues remaining in the centrifuge tubes after adsorption experiments were collected and washed with DI water carefully three times to remove any possibly unabsorbed ions, and then dried at a constant temperature of $50{ }^{\circ} \mathrm{C}$. The obtained samples were denoted as amendments with $\mathrm{Cd}$ loading (Ads-Cd). As changes in $\mathrm{pH}$ and ionic strength would significantly affect the effectiveness of amendments, which in turn would change the adsorption capacity and affect the transport of $\mathrm{Cd}$ in the medium, Ads-Cd were applied in the following procedures to illustrate the effects of $\mathrm{pH}$ and ion strength on $\mathrm{Cd}$ desorption.

\subsubsection{Effect of $\mathrm{pH}$}

$\mathrm{NaNO}_{3}\left(0.01 \mathrm{~mol} \mathrm{~L}^{-1}\right)$ was again used as background electrolyte, while the solution $\mathrm{pH}$ was adjusted to $1,2,3$, and 5 individually by $0.1 \mathrm{~mol} \mathrm{~L}^{-1} \mathrm{HCl}$ and $\mathrm{NaOH}$ solutions. DI water was used as the treatment of $\mathrm{pH} 7$ as the control. It should be noted that $\mathrm{pH}$ below 4 is less relevant to natural conditions, the critical criterion for examining the stability of soil remediation, thus $\mathrm{pH}$ of 3.0 was set. While the gradient of $\mathrm{pH}$ value should usually be set to exceed the threshold, in this experiment, we aimed to understand the maximum amount of cadmium desorption at very low $\mathrm{pH}$, so the ultimate $\mathrm{pH}$ was set as low as 1.0 in this study. Part of the collected Ads-Cd samples (0.2 g) was equilibrated with $30 \mathrm{~mL}$ of the prepared solutions in a rotatory shaker at $180 \mathrm{r} \mathrm{min}^{-1}$ and $25 \pm 2{ }^{\circ} \mathrm{C}$ for $24 \mathrm{~h}$. Centrifugation at $5000 \mathrm{r} \mathrm{min}^{-1}$ for $30 \mathrm{~min}$ was used to separate the supernatant and solid residues and then the supernatant was filtered through a $0.45 \mu \mathrm{m}$ membrane pore size filter, the collected filtrate was subjected to a PerkinElmer 1100B atomic absorption spectrometer for determination of Cd concentration. 


\subsubsection{Effect of Ion Strength}

Similar procedure was adopted in examining the effect of ion strength. Differently, background electrolyte $\mathrm{NaNO}_{3}$ was prepared in the concentrations of $0,0.01,0.05,0.1$ and $0.2 \mathrm{~mol} \mathrm{~L}^{-1}$ by DI water. Specifically, $0.2 \mathrm{~g}$ of the collected Ads-Cd samples were equilibrated with $30 \mathrm{~mL}$ of the prepared solutions in a rotatory shaker at $180 \mathrm{r} \mathrm{min}-1$ and $25 \pm 2{ }^{\circ} \mathrm{C}$ for $24 \mathrm{~h}$. The solid residues and supernatant were separated by centrifugation (5000 $\mathrm{r} \mathrm{min}^{-1}$ for $30 \mathrm{~min}$ ), and then filtered through a $0.45 \mu \mathrm{m}$ membrane pore size filter. The collected filtrate was subjected to a PerkinElmer 1100B atomic absorption spectrometer for determination of $\mathrm{Cd}$ concentration. Each desorption treatment was carried out in triplicate.

\subsection{Statistical Analysis}

Langmuir and Freundlich isotherms were used to analyze the experimental data for $\mathrm{Cd}$ ions adsorption onto the amendments to evaluate the parameters directly related to the adsorption process.

The monolayer adsorption process was successfully characterized by Langmuir isotherm:

$$
\begin{aligned}
& \mathrm{x} / \mathrm{m}=\left[\left(\mathrm{C}_{0}-\mathrm{C}_{\mathrm{e}}\right)\right] / \mathrm{m} \times \mathrm{V}, \\
& \mathrm{C}_{\mathrm{e}} /(\mathrm{x} / \mathrm{m})=1 / \mathrm{K}_{\mathrm{l}} \mathrm{b}+\mathrm{C}_{\mathrm{e}} / \mathrm{b},
\end{aligned}
$$

where $\mathrm{C}_{0}\left(\mathrm{mg} \mathrm{L}^{-1}\right)$ is the initial concentration of $\mathrm{Cd}, \mathrm{C}_{\mathrm{e}}$ is the concentration of $\mathrm{Cd}$ in solution at equilibrium ( $\left.\mathrm{mg} \mathrm{L}^{-1}\right), \mathrm{V}$ is the volume of equilibrium solution $(\mathrm{mL}), \mathrm{m}$ is the quality of the amendment $(\mathrm{g}), \mathrm{x} / \mathrm{m}$ is the adsorbed $\mathrm{Cd}$ per gram at equilibrium $\left(\mathrm{mg} \mathrm{g}^{-1}\right), \mathrm{b}$ is the maximum adsorption capacity of $\mathrm{Cd}\left(\mathrm{mg} \mathrm{g}^{-1}\right)$, and $\mathrm{K}_{1}$ is a constant related to the binding energy of $\mathrm{Cd}$ on amendments $\left(\mathrm{L} \mathrm{mg}^{-1}\right)$.

The Freundlich isotherm is considered as a semi-empirical equation to characterize the adsorption on heterogeneous surface, which can be presented in the following form:

$$
\begin{gathered}
\mathrm{x} / \mathrm{m}=\mathrm{K}_{\mathrm{F}} \mathrm{C}_{\mathrm{e}}, \\
\lg \mathrm{x} / \mathrm{m}=\lg \mathrm{K}_{\mathrm{F}}+1 / \operatorname{nlg}_{\mathrm{e}},
\end{gathered}
$$

where $x / m$ is the quantity of adsorbed Cd per gram at equilibrium $(\mathrm{mg} / \mathrm{g}), \mathrm{C}_{\mathrm{e}}$ is the concentration of $\mathrm{Cd}$ in equilibrium solution $\left(\mathrm{mg} \mathrm{L}^{-1}\right), \mathrm{K}_{\mathrm{F}}$ is Freundlich adsorption coefficient $\left(\mathrm{L} \mathrm{mg}^{-1}\right)$, and $\mathrm{n}$ is a parameter reflecting the intensity of sorption.

The desorption efficiency (D, \%) of Cd from Ads-Cd was calculated by:

$$
\mathrm{D}=\left[\left(\mathrm{C}_{\mathrm{d}}-\mathrm{C}_{\mathrm{e}}\right) /\left(\mathrm{C}_{0} \max -\mathrm{C}_{\mathrm{e}}\right] \times 100 \%,\right.
$$

where $\mathrm{C}_{0}$ max is the initial concentration of $\mathrm{Cd}\left(120 \mathrm{mg} \mathrm{L}^{-1}\right.$ in this study), and $\mathrm{Cd}$ is the desorption equilibrium concentration of $\mathrm{Cd}\left(\mathrm{mg} \mathrm{L}^{-1}\right)$.

The data were also subjected to one-way ANOVA analysis using SPSS 16.0 (SPSS, Inc., Chicago, IL, USA), and Duncan's Multiple Range test was used to determine the differences $(p<0.05)$ between means. All data were fitted to the normal distribution before conducting one-way ANOVA.

\section{Results and Discussion}

\subsection{Characterization of Amendments}

The particle size and BET surface area of Ads before and after $\mathrm{Cd}$ adsorption are summarized in Table 2. The particle size increased while BET surface area decreased after Cd-loading on Ads, which might be explained by the fact that reactions such as electrostatic adsorption, surface precipitation, complexation etc. occurred with the adsorption of $\mathrm{Cd}$. 
Table 2. Particle size and BET surface area of amendments with/out Cd loading. Ads and Ads-Cd, respectively, represent the amendments before cadmium adsorbed and after Cd loaded. Significant differences are indicated by different lowercase letters $(p<0.05)$ (these comparisons were done separately for the parameters in each column.

\begin{tabular}{ccccc}
\hline \multirow{2}{*}{ Amendments } & \multicolumn{2}{c}{ Particle Mean Size $(\boldsymbol{\mu m})$} & \multicolumn{2}{c}{ BET Surface Area $\left.\mathbf{( m}^{\mathbf{2}} \mathbf{g}^{-\mathbf{1}}\right)$} \\
\cline { 2 - 5 } & Ads & Ads-Cd & Ads & Ads-Cd \\
\hline Ad1 & $7.293 \pm 1.274 \mathrm{~d}$ & $9.108 \pm 1.541 \mathrm{c}$ & $58.704 \pm 2.755 \mathrm{a}$ & $47.171 \pm 2.222 \mathrm{a}$ \\
Ad2 & $14.596 \pm 1.713 \mathrm{c}$ & $17.033 \pm 1.437 \mathrm{~b}$ & $21.271 \pm 1.897 \mathrm{c}$ & $5.220 \pm 0.637 \mathrm{c}$ \\
Ad3 & $35.902 \pm 3.799 \mathrm{a}$ & $37.117 \pm 3.215 \mathrm{a}$ & $4.632 \pm 0.515 \mathrm{~d}$ & $2.634 \pm 0.506 \mathrm{c}$ \\
Ad4 & $29.599 \pm 2.271 \mathrm{~b}$ & $33.304 \pm 2.434 \mathrm{a}$ & $36.512 \pm 1.205 \mathrm{~b}$ & $10.124 \pm 1.557 \mathrm{~b}$ \\
\hline
\end{tabular}

Inorganic minerals before and after $\mathrm{Cd}$ adsorption on the surfaces of soil amendments were identified by XRD analysis. As shown in Figure 1, in addition to the main minerals detected such as crystalline calcite $\left(\mathrm{CaCO}_{3}\right)$, quartz $\left(\mathrm{SiO}_{2}\right)$, soda or potash feldspar $\left(\mathrm{NaAlSi}_{3} \mathrm{O}_{8}\right.$ or $\left.\mathrm{KAlSi}_{3} \mathrm{O}_{8}\right)$, etc., new diffraction peaks at $2 \theta=28.1^{\circ}$ and $37.0^{\circ}$ corresponding to chemicals of $\mathrm{Cd}(\mathrm{OH})_{2}$ and $\mathrm{CdCO}_{3}$, respectively, were found on the surfaces of Ads-Cd. It might be explained by the fact that the Ads tend to release anions (e.g., $\mathrm{CO}_{3}{ }^{2-}$ ) which bond with $\mathrm{Cd}$ to form precipitates; similarly, functional group such as $\mathrm{C}-\mathrm{OH}$ on the surface of Ads might promote the occurrence of complexation reactions during $\mathrm{Cd}$ sorption. As previous studies reported that some metal cations such as $\mathrm{Ca}, \mathrm{Fe}$ and $\mathrm{Mg}$ ions can be modified and replaced by $\mathrm{Cd}$ ions in the lattice of base and clay minerals by ion exchange [34], in this study, we found that $\mathrm{CaMg}\left(\mathrm{CO}_{3}\right)_{2}$ in $\mathrm{Ad} 1$ was replaced by $\mathrm{CaCd}\left(\mathrm{CO}_{3}\right)_{2}$, indicating ion exchange might take place on the surface of Ad1 with Cd sorption. Similarly, the replacement of $\mathrm{Cd}$ also took place on the surface of Ad2. XRD analysis suggested the phenomena of isomorphic substitution where probably the $\mathrm{Al}^{3+}$ ions of the zeolite or attapulgite framework were substituted with exchanged $\mathrm{Cd}^{2+}$ ions. Similar phenomenon was observed in previous studies [34]. Therefore, the principal mechanism being responsible for $\mathrm{Cd}$ adsorption on $\mathrm{Ad} 1$ and $\mathrm{Ad} 2$ was ion exchange, which might be followed by surface precipitation or complexation. These mechanisms might have occurred simultaneously or supplemented each other.

However, it should be noted that XRD is specialized with its application mainly concentrating on crystal identification and crystal structure analysis. While sometimes XRD cannot accurately detect the diffraction peaks of all substances due to the possible reasons that the formed particles are too small (as in the case of many precipitation reactions), the materials being formed are not crystalline or their concentration is too low for detection. Therefore, more investigation is further needed to determine the sorption mechanism of $\mathrm{Cd}$ by amendments.
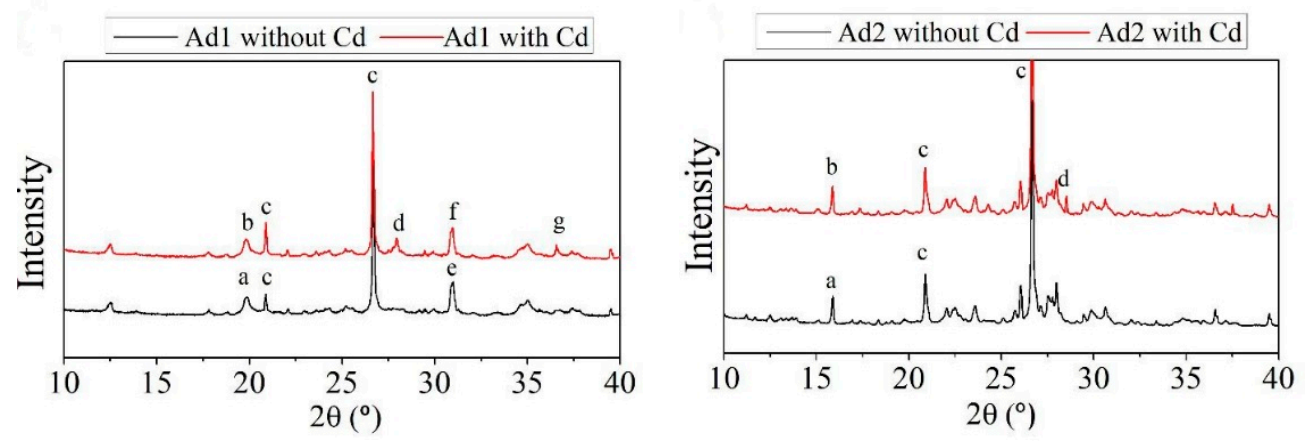

Figure 1. Cont. 

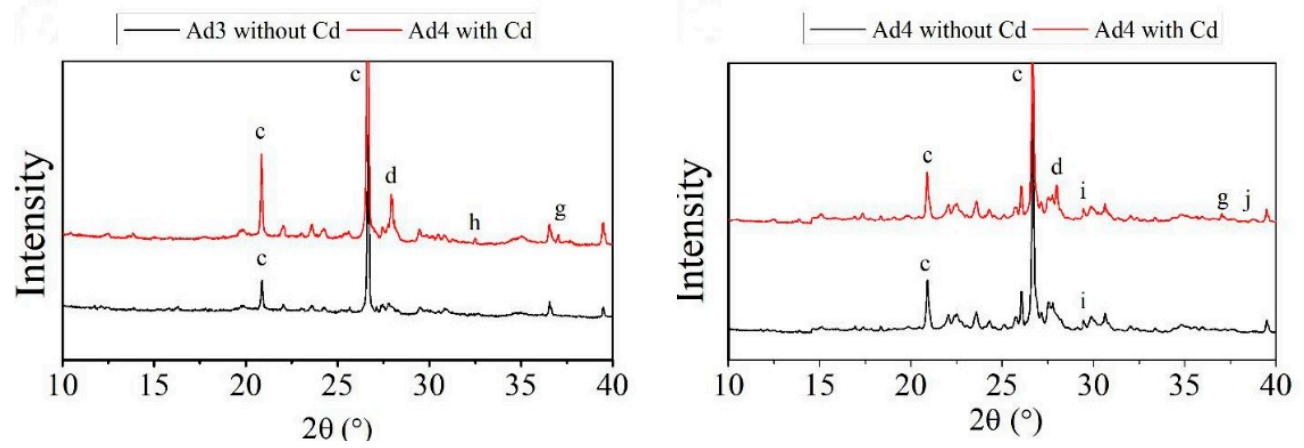

Figure 1. X-ray diffraction patterns of amendments with/out $\mathrm{Cd}$ loading $\left(\mathrm{a}=\mathrm{KAlSi}_{3} \mathrm{O} ; \mathrm{b}=\mathrm{KAlCdSi}_{2} \mathrm{O}_{8}\right.$; $\mathrm{c}=\mathrm{SiO}_{2} ; \mathrm{d}=\mathrm{Cd}(\mathrm{OH})_{2} ; \mathrm{e}=\mathrm{CaMg}\left(\mathrm{CO}_{3}\right)_{2} ; \mathrm{f}=\mathrm{CaCd}\left(\mathrm{CO}_{3}\right)_{2} ; \mathrm{g}=\mathrm{CdCO}_{3} ; \mathrm{h}=\mathrm{KCdCl}_{3} ; \mathrm{i}=\mathrm{CaCO}_{3}$; $\mathrm{j}=\mathrm{Cd}(\mathrm{OH}) \mathrm{Cl})$.

In the case of $\mathrm{Ad} 3$, except for $\mathrm{Cd}(\mathrm{OH})_{2}$ and $\mathrm{CdCO}_{3}$, a new diffraction peak $2 \theta=32.6^{\circ}$ representing $\mathrm{KCdCl}_{3}$ was observed after the loading of $\mathrm{Cd}$. A new diffraction peak of around $2 \theta=38.7^{\circ}$ was observed with $\mathrm{Cd}$ loading, indicating the formation of complex $\mathrm{Cd}(\mathrm{OH}) \mathrm{Cl}$, related to the complexation between $\mathrm{Cd}^{2+}$ and organic functional groups (e.g., C-O, C-OH, C-O-C) on the surface of Ad4 [35].

\subsection{Cd Adsorption on Amendments}

The Langmuir and Freundlich models were used to simulate the adsorption isotherms of $\mathrm{Cd}$ on the amendments. The Langmuir and Freundlich parameters derived from Equations (2) and (4) and their correlation coefficients $\left(\mathrm{R}^{2}\right)$ are presented Table 3. The adsorption of $\mathrm{Cd}$ on amendments obeyed Langmuir and Freundlich adsorption isotherms well with $\mathrm{R}^{2}>0.87$, and the maximum adsorption capacity (b) on Cd of the test amendments ranged from 7.47 to $17.67 \mathrm{mg} \mathrm{g}^{-1}$ and followed the order of: Ad3 $>$ Ad4 $>$ Ad1 $>$ Ad2. The predictions of both Langmuir or Freundlich isotherms showed similar trends in their corresponding adsorption coefficients or binding energy on Cd (k) (Table 3). It is important to note that slightly better fit of $\mathrm{Ad} 3$ and $\mathrm{Ad} 4$ adsorption of $\mathrm{Cd}$ was obtained using Langmuir model than that from Freundlich model, suggesting that the behavior of $\mathrm{Cd}$ adsorption onto Ad3 and Ad4 was more consistent with the Langmuir model, than that of Freundlich. Hence, it can be assumed that adsorption of $\mathrm{Cd}$ by $\mathrm{Ad} 3$ and $\mathrm{Ad} 4$ mainly occurred in monolayers, or through a fixed number of identical, and energetically equivalent sites on the surface. In contrast, higher correlation coefficients from Freundlich model was achieved at Ad1 and Ad2 adsorption of Cd than that from Langmuir as shown in Table 3, indicating Ad1 and Ad2 might apply multi-layer adsorption and surface adsorption under a variety of unideal conditions, as described by the Freundlich model, a semi-empirical equation [36].

Table 3. Parameters of Langmuir and Freundlich isotherms for the adsorption of Cd (aq) on the amendments.

\begin{tabular}{ccccccc}
\hline \multirow{2}{*}{ Amendments } & \multicolumn{3}{c}{ Langmuir Isotherm } & \multicolumn{3}{c}{ Freundlich Isotherm } \\
\cline { 2 - 7 } & $\mathbf{b}$ & $\mathbf{K}_{\mathbf{1}}$ & $\mathbf{R}^{\mathbf{2}}$ & $\mathbf{l g} \mathbf{K}_{\mathbf{F}}$ & $\mathbf{1 / n}$ & $\mathbf{R}^{\mathbf{2}}$ \\
\hline Ad1 & 8.711 & 0.095 & 0.875 & 1.6144 & 0.6042 & 0.960 \\
Ad2 & 7.474 & 0.131 & 0.942 & 1.5788 & 0.5823 & 0.978 \\
Ad3 & 17.668 & 0.832 & 0.973 & 2.8511 & 0.7192 & 0.958 \\
Ad4 & 12.821 & 0.204 & 0.931 & 2.3442 & 0.731 & 0.907 \\
\hline
\end{tabular}

Note: $\mathrm{b}$ is the maximum adsorption capacity $\left(\mathrm{mg} \mathrm{g}^{-1}\right) ; \mathrm{K}_{\mathrm{l}}$ is the Langmuir constant related to the sorption energy $\left(\mathrm{L} \mathrm{mg}^{-1}\right) ; \mathrm{n}$ is the Freundlich constant related to surface heterogeneity; $\mathrm{K}_{\mathrm{F}}$ is the Freundlich constant related to sorption capacity $\left(\mathrm{L} \mathrm{mg}^{-1}\right)$; and $\mathrm{R}^{2}$ is the correlation coefficients.

As shown in Table 3, Ad3 was the most effective in adsorbing Cd from solutions among all amendments. There are at least three possible reasons. Firstly, humus can contain abundant humic 
substances (e.g., humic acid, fulvic acid and humin); because of their deprotonation in weakly acidic to basic media, humic substances have negative charge and improve the sorption of $\mathrm{Cd}$ by electrostatic attraction and/or complexation $[37,38]$.

In addition, humic substances can form aggregates with mineral particles, which significantly enhances adsorption and complexation of heavy metal ions [31]. Another reason might be related to a mass of microorganisms (e.g., bacteria, actinomycetes and fungi) included by humus, because the cell walls of these microorganisms or the byproducts synthesized by microorganisms such as antibiotics, enzymes, flavoring agents and organic acids could directly deposit heavy metals by physical adsorption or inorganic precipitation $[39,40]$. The adsorption mechanism of Ad4 on Cd in solutions is different from that of Ad3. Electrostatic attraction with anions such as Cd could occur on the negatively charged surface of biochar [41]. The electron-rich domains on functional groups of biochar bearing $\pi$-electrons such as $\mathrm{C}=\mathrm{O}$ or $\mathrm{C}=\mathrm{C}$ to form cation $-\pi$ interactions with $\mathrm{Cd}$ can also be associated with $\mathrm{Cd}$ adsorption $[35,42,43]$. Finally, ion exchange of $\mathrm{Cd}$ with exchangeable cations such as calcium and magnesium ions on biochar could also be an important adsorption mechanism [35,44].

It is evident in Table 3 that Ad3 and Ad4 were more effective in absorbing Cd than Ad1 and Ad2, and the adsorption capacity of Ad3 almost doubled that of Ad1 and Ad2 in both Langmuir and Freundlich models. Generally, the adsorption capacity of amendments on heavy metals is believed to depend on their polarity, pore size distribution, surface morphology, surface area, functional groups attached to the sorbent surface, etc. [45]. The mechanisms of adsorbing heavy metals by clay or rock materials primarily contain ion exchange, surface complexation ("innersphere" or "outersphere"), lattice diffusion, isomorphic substitution within the mineral lattice, etc. [46,47].

\subsection{Cd Desorption from Amendment-Cd}

\subsubsection{Effect of $\mathrm{pH}$}

The desorption of $\mathrm{Cd}$ from Ads-Cd into solutions was evaluated to investigate the stabilization of $\mathrm{Cd}$ on amendments in media (soils or waters). The effect of $\mathrm{pH}$ and ion strength on $\mathrm{Cd}$ desorption were determined and calculated by Equation (5). The effect of $\mathrm{pH}$ on the desorption percentages of $\mathrm{Cd}$ is shown in Figure 2. All treatments significantly increased the desorption percentages of $\mathrm{Cd}$ when compared with the control $(\mathrm{pH}=7)$. It is worth noting that, when ion-exchange or chemical bonding dominates the adsorption of $\mathrm{Cd}$ on amendments, its associated desorption could be facilitated by strong acid or alkali solutions. In contrast, if physical bonding plays the key role, then just water (control treatment) can cause its desorption [48]. The results again indicate that possibly several retention processes such as ion exchange, surface sorption, diffusion, precipitation, etc. contributed simultaneously toward $\mathrm{Cd}$ stabilization by amendments. In addition, lower $\mathrm{pH}$ values ( 1.0 or $2.0 \mathrm{vs.} 3.0$ or 5.0) resulted in statistically increased desorption percentages, as shown in Figure 2, which could be explained as the increased amounts of $\mathrm{H}^{+}$or corresponding more positive charges with the decrease of $\mathrm{pH}$ values in solutions compete with $\mathrm{Cd}$ ions that were already fixed in amendments, further liberating more Cd.
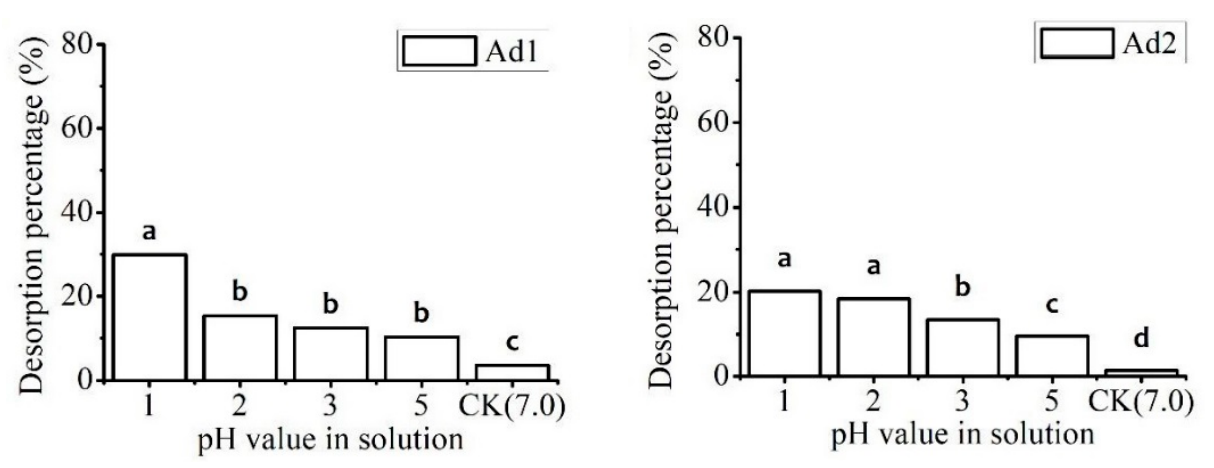

Figure 2. Cont. 

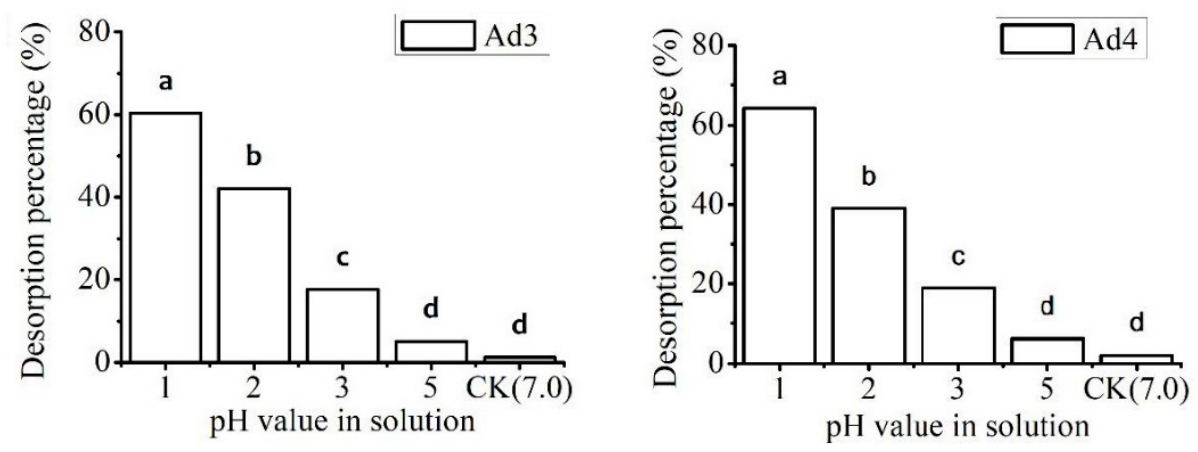

Figure 2. Effect of $\mathrm{pH}$ on desorption efficiency of $\mathrm{Cd}$ from Ads-Cd (ion strength was $0.1 \mathrm{M}$ ). Error bars represent standard deviations, and bars with different letters are significantly different at $p<0.05$.

A closer look at Figure 2 reveals that there was no big difference in $\mathrm{Cd}$ desorption at higher $\mathrm{pHs}(>3)$ under all different amendments with the desorption percentages of less than $20 \%$, but their significant increase was found with $\mathrm{pH}$ decreased from 3 to 2, particularly for Ad3 and Ad4, in which the desorption percentages almost doubled. In addition, up to $40-70 \%$ of desorption rate at extremely low $\mathrm{pH}$ ( 1 or 2 ) for Ad3 and Ad4 was observed in Figure $2 \mathrm{c}, \mathrm{d}$, which was much higher than that obtained by $\mathrm{Ad} 1$ and $\mathrm{Ad} 2(15-30 \%)$. In the case of $\mathrm{Ad} 3$, more $\mathrm{H}^{+}$in the solutions with lower $\mathrm{pH}$ values resulting in apparently release of $\mathrm{Cd}$ can be explained by the fact that the carboxyl functional groups of humic acids were protonated to a higher extent with lower $\mathrm{pH}$ values $(<3.0)$ and resulted in a stronger repulsion for positively charged cations such as $\mathrm{Cd}$ in the solutions. However, the carboxyl groups were deprotonated and favored the aggregation of $\mathrm{Cd}$ at $\mathrm{pHs}$ greater than 4.0 [49]. It also should be noted that most microorganism cells are kept negatively charged within the $\mathrm{pH}$ range 5.0-9.0, which was the reason that $\mathrm{Cd}$ adsorbed by $\mathrm{Ad} 3$ became more stable at $\mathrm{pH}$ greater than 5 (Figure 2c) [50]. Similarly, for Ad4, the functional groups including phenolic hydroxyl, carboxyl, carbonyl, etc. on the surface of biochar, which were partially responsible for $\mathrm{Cd}$ adsorption, also changed their charges with the decrease of $\mathrm{pH}$. Thus, the competition between metal cations and protons for surface adsorption sites on biochar occurred further resulted in the release of Cd (Figure 2d) [51,52].

\subsubsection{Effect of Ion Strength}

The effect of ion strength adjusted by $\mathrm{NaNO}_{3}$ with a stable $\mathrm{pH}$ value of 7 on the desorption of $\mathrm{Cd}$ is displayed in Figure 3. The desorption percentage of $\mathrm{Cd}$ from Ads-Cd increased significantly under all treatments compared with the control except for the ion strength of $0.1 \mathrm{~mol} / \mathrm{L}$, in which the number of ions was probably not sufficient to replace $\mathrm{Cd}$ from the adsorption sites of Ads. It can also be found that the release of $\mathrm{Cd}$ was significantly increased with ion strength increased (from 0.05 to $0.2 \mathrm{~mol} \mathrm{~L}^{-1}$ ) (Figure 3), which can probably be explained by the following reasons: Firstly, with the concentration of $\mathrm{NO}_{3}{ }^{-}$increasing in Cd ion solution, it was possible to form uncharged species and negatively charged nitrate complexes that could weak the electrostatic interaction between Ads and $\mathrm{Cd}$, and then inevitably decrease the sorption capacity of the adsorbents.

Secondly, high ionic strength could enhance the competition ability of $\mathrm{Na}^{+}$for deprotonated binding sites on Ads which already were occupied by $\mathrm{Cd}$, thus promoting the desorption of $\mathrm{Cd}$ [53]. Finally, the electrolyte ions might form ion pair with $\mathrm{Cd}$, and $\mathrm{Na}^{+}$with much smaller radius may cause steric hindrance to $C d$, which could reduce the chance of $C d$ exposure to Ads [54]. It also should be noted that generally, precipitation, diffusion, surface sorption, ion exchange, etc. contribute simultaneously toward $\mathrm{Cd}$ stabilization by amendments, as previously mentioned. The forms of desorbed $\mathrm{Cd}$ ions from Ads-Cd into the solution might include loosely bound cadmium, precipitated $\mathrm{Cd}$, ion exchanged $\mathrm{Cd}$, and carboxyl $\mathrm{Cd}$, under different environmental parameter values $(\mathrm{pH}$ and ion strength). 

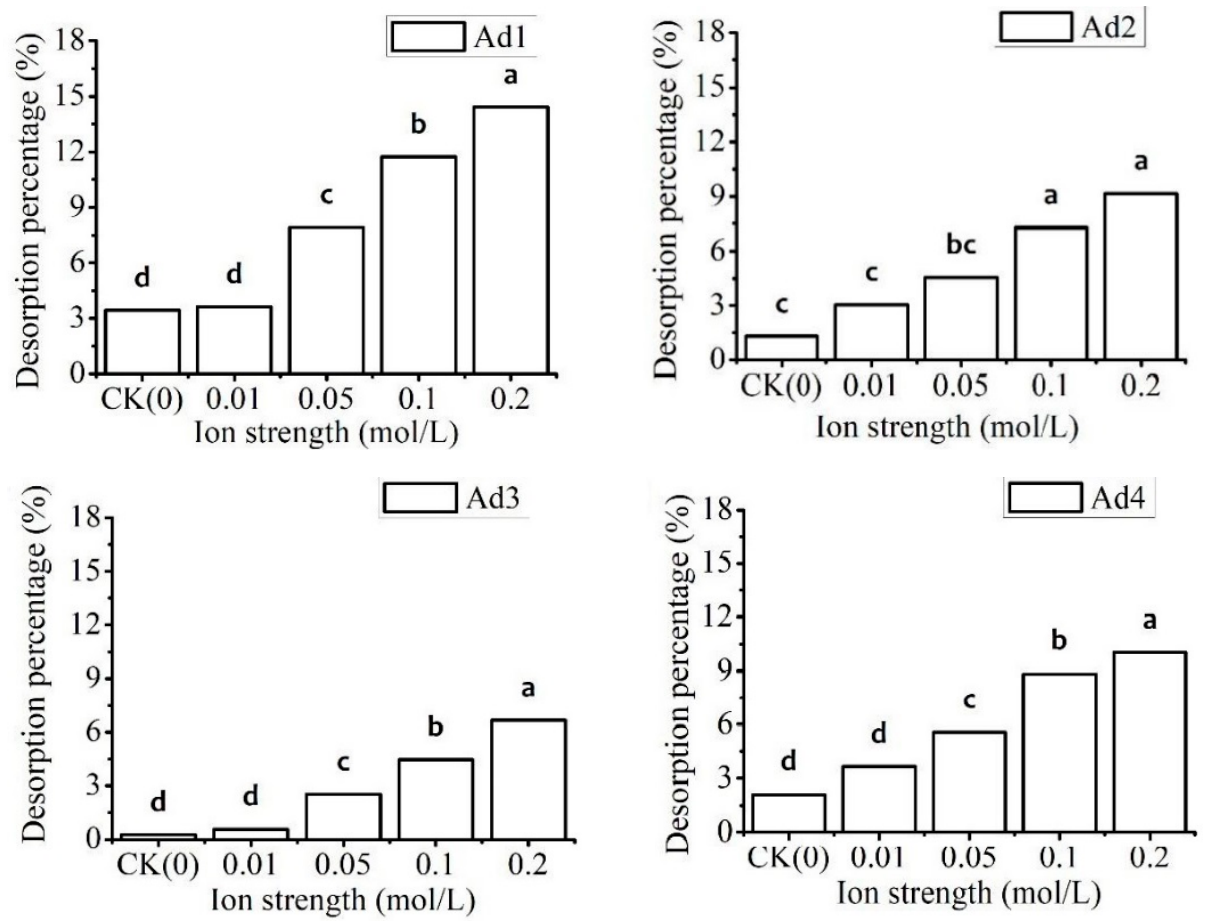

Figure 3. Effect of ion strength on desorption efficiency of $\mathrm{Cd}$ from Ads-Cd ( $\mathrm{pH}$ was 7). Error bars represent standard deviations, and bars with different letters are significantly different at $p<0.05$.

\subsection{Environmental Implications}

It is worth noting that, in China, the acid soils account for up to $21 \%$ of total agricultural land with $\mathrm{pH}$ values below 6.0, but, even with severely acidification conditions, less is below 5.0 [54,55]. In addition, the ion strength of Chinese typical soils usually is less than $0.1 \mathrm{M}$. Based on Figure 3, there was no more than $12 \%$ desorption rate of $\mathrm{Cd}$ from test amendments when the ion strength was less than $0.1 \mathrm{M}$. The results indicate that these soil amendments can be potentially applied in in situ remediation of $\mathrm{Cd}$ contaminated farmland in China. Comparatively, as shown in Figures 2 and 3, there was a small increase of desorption rate of $\mathrm{Cd}$ from Ad3 and Ad4, followed by Ad2 and then Ad1 with ion strength increase or $\mathrm{pH}$ decrease, which is because the accessibility (or "activity") of $\mathrm{Cd}$ combining with functional group sites on the surfaces of Ad3 or Ad4 were much stronger [56]. Therefore, Ad3 and Ad4 could be more effective for in situ stabilization of $\mathrm{Cd}$ in polluted soils, due to their high adsorption capacities (12.82 and $17.67 \mathrm{mg} \mathrm{g}^{-1}$, respectively) and low desorption percentages (4.46-6.23\%) at $\mathrm{pH}$ from 5 to 7 and ion strengths from 0.01 to $0.1 \mathrm{~mol} / \mathrm{L}$. The results obtained in this study could provide theoretical foundation for in-situ remediation of $\mathrm{Cd}$ polluted field-soil in China. However, it should be noted that an ideal amendment for effectively reducing metal bioavailability should have the following characteristics: no leaching, inexpensive, easy to handle and apply, highly available and/or easy to produce, safe for workers, compatible with and non-toxic to the plants, and not cause secondary pollution to the site. Furthermore, the applied amendments could offer benefits to the plants (e.g., supply plant nutrients, improve plant growth, increase plant resistance against diseases, etc.). No real-life cycle assessment on the effects, advantages and drawbacks of various amendments has been performed thus far and the efficiency of the amendment is site (or soil) specific.

\section{Conclusions}

The soil amendments were found effective in stabilizing $\mathrm{Cd}$ from aqueous solutions. The maximum adsorption capacity of test amendments on Cd ranged from 7.47 to $17.67 \mathrm{mg} \mathrm{g}^{-1}$ and followed the order of: $\mathrm{Ad} 3>\mathrm{Ad} 4>\mathrm{Ad} 1>\mathrm{Ad} 2$. Decreasing $\mathrm{pH}$ (from 7 to 1) or increasing ion 
strength (from 0 to $0.2 \mathrm{M}$ ) significantly increased the desorption percentages of $\mathrm{Cd}$ from amendments. Considering the associated characteristics of typical soils in China (generally with $\mathrm{pH}$ greater than 3 or ion strength less than $0.1 \mathrm{M}$ ), the desorption percentages of $\mathrm{Cd}$ were less than $20 \%$ and $12 \%$, respectively, at these conditions. The results indicate that the test amendments displayed great potential for stabilizing $\mathrm{Cd}$ in contaminated soils. Comparatively, $\mathrm{Ad} 3$ and $\mathrm{Ad} 4$ seemed to be more promising amendments for in situ immobilization of $\mathrm{Cd}$ in contaminated soils, due to their high adsorption capacities and low desorption percentage at higher $\mathrm{pH}$ values and ion strengths less than $0.1 \mathrm{M}$. This study fully demonstrates that addition of soil amendments could be effective for in-situ remediation of $\mathrm{Cd}$ polluted field-soil. The procedure of $\mathrm{Cd}$ adsorption and desorption can provide the reference for land managers when they apply amendments to control or reduce $\mathrm{Cd}$ contamination in agricultural lands.

Author Contributions: Conceptualization, S.C.; Data curation, S.L.; Methodology, S.L.; Project administration, S.C.; Resources, C.M.; Supervision, M.W.; Validation, Z.Z.; Writing-original draft, S.L.; and Writing-review and editing, M.W.

Funding: This research was funded by [National Key Research and Development Program of China] grant number [2016YFD0800707]; [National Key Technology R\&D Program of China] grant number [2015BAD05B03]; and [Natural Science Foundation of China] grant number [41271490 and 21706278].

Conflicts of Interest: The authors declare no conflict of interest.

\section{References}

1. Solgi, E.; Esmaili-Sari, A.; Riyahi-Bakhtiari, A.; Hadipour, M. Soil contamination of metals in the three industrial estates, Arak, Iran. Bull. Environ. Contam. Toxicol. 2012, 88, 634-642. [CrossRef] [PubMed]

2. Yang, Q.Q.; Li, Z.Y.; Lu, X.N.; Duan, Q.N.; Huang, L.; Bi, J. A review of soil heavy metal pollution from industrial and agricultural regions in China: Pollution and risk assessment. Sci. Total Environ. 2018, 642, 690-700. [CrossRef] [PubMed]

3. Liu, L.; Li, W.; Song, W.; Guo, M. Remediation techniques for heavy metal-contaminated soils: Principles and applicability. Sci. Total Environ. 2018, 633, 206-219. [CrossRef] [PubMed]

4. Rafiq, M.T.; Aziz, R.; Yang, X.; Xiao, W.; Rafiq, M.K.; Ali, B.; Li, T. Cadmium phytoavailability to rice (Oryza sativa L.) grown in representative Chinese soils. A model to improve soil environmental quality guidelines for food safety. Ecotoxicol. Environ. Saf. 2014, 103, 101-107. [CrossRef] [PubMed]

5. Tang, X.; Li, Q.; Wu, M.; Lin, L.; Scholz, M. Review of remediation practices regarding cadmium-enriched farmland soil with particular reference to china. J. Environ. Manag. 2016, 181, 646-662. [CrossRef] [PubMed]

6. Bolan, N.; Kunhikrishnan, A.; Thangarajan, R.; Kumpiene, J.; Park, J.; Makino, T.; Kirkham, M.B.; Scheckel, K. Remediation of heavy metal(loid)s contaminated soils-to mobilize or to immobilize? J. Hazard Mater. 2014, 266, 141-166. [CrossRef] [PubMed]

7. Williams, P.N.; Lei, M.; Sun, G.; Huang, Q.; Lu, Y.; Deacon, C.; Meharg, A.A.; Zhu, Y.G. Occurrence and partitioning of cadmium, arsenic and lead in mine impacted paddy rice: Hunan, China. Environ. Sci. Technol. 2009, 43, 637-642. [CrossRef] [PubMed]

8. Li, Z.; Ma, Z.; Van, T.J.; Yuan, Z.; Huang, L. A review of soil heavy metal pollution from mines in China: Pollution and health risk assessment. Sci. Total Environ. 2014, 468-469, 843-853. [CrossRef] [PubMed]

9. Zhuang, P.; Li, Z.A.; Mcbride, M.B.; Zou, B.; Wang, G. Health risk assessment for consumption of fish originating from ponds near dabaoshan mine, south China. Environ. Sci. Pollut. Res. Int. 2013, 20, 5844-5854. [CrossRef] [PubMed]

10. Nabulo, G.; Young, S.D.; Black, C.R. Assessing risk to human health from tropical leafy vegetables grown on contaminated urban soils. Sci. Total Environ. 2010, 408, 5338-5351. [CrossRef] [PubMed]

11. Żukowska, J.; Biziuk, M. Methodological evaluation of method for dietary heavy metal intake. J. Food Sci. 2008, 73, 21-29. [CrossRef] [PubMed]

12. Wu, Y.; Chen, Y. Food safety in China. J. Epidem. Commun. Health. 2013, 67, 478-479. [CrossRef] [PubMed] 
13. Gao, Z.; Fu, W.; Zhang, M.; Zhao, K.; Tunney, H.; Guan, Y. Potentially hazardous metals contamination in soil-rice system and it's spatial variation in shengzhou city, China. J. Geochem. Explor. 2016, 167, 62-69. [CrossRef]

14. Porter, S.K.; Scheckel, K.G.; Impellitteri, C.A.; Ryan, J.A. Toxic metals in the environment: Thermodynamic considerations for possible immobilization strategies for $\mathrm{Pb}, \mathrm{Cd}, \mathrm{As}$, and $\mathrm{Hg}$. Crit. Rev. Environ. Sci. Technol. 2004, 34, 495-604. [CrossRef]

15. Yao, Z.; Li, J.; Xie, H.; Yu, C. Review on remediation technologies of soil contaminated by heavy metals. Procedia Environ. Sci. 2012, 16, 722-729. [CrossRef]

16. Wang, Q.R.; Dong, Y.; Cui, Y.; Liu, X. Instances of soil and crop heavy metal contamination in China. Soil Sediment. Contam. 2001, 10,497-510. [CrossRef]

17. Rahman, I.M.M.; Begum, Z.A.; Sawai, H. Solidification/stabilization: A remedial option for metal contaminated soils. In Environmental Remediation Technologies for Metal-Contaminated Soils; Hasegawa, H., Rahman, I.M.M., Rahman, M.A., Eds.; Springer: Tokyo, Japan, 2016; pp. 125-146. [CrossRef]

18. Koptsik, G.N. Modern approaches to remediation of heavy metal polluted soils: A review. Eurasian Soil Sci. 2014, 47, 707-722. [CrossRef]

19. Priya, S.V.; Arulmozhi, M. Biosorbents for toxic heavy metals-A review. In Proceedings of the International Conference on Advances in Engineering, Science and Management, Nagapattinam, India, 30-31 March 2012; pp. 221-230.

20. Sun, Y.; Sun, G.; Xu, Y.; Liu, W.; Liang, X.; Wang, L. Evaluation of the effectiveness of sepiolite, bentonite, and phosphate amendments on the stabilization remediation of cadmium-contaminated soils. J. Environ. Manag. 2005, 166, 204-210. [CrossRef] [PubMed]

21. Tlustos, P.; Szakova, J.; Korinek, K.; Pavlikova, D.; Hanc, A.; Balik, J. The effect of liming on cadmium, lead and zinc uptake reduction by spring wheat grown in contaminated soil. Plant Soil Environ. 2006, 52, 16-24. [CrossRef]

22. Ahmad, I.; Akhtar, M.J.; Zahir, Z.A.; Mitter, B. Organic amendments: Effects on cereals growth and cadmium remediation. Int. J. Environ. Sci. Technol. 2015, 12, 2919-2928. [CrossRef]

23. Clemente, R.; Almela, C.; Bernal, M.P. A remediation strategy based on active phytoremediation followed by natural attenuation in a soil contaminated by pyrite waste. Environ. Pollut. 2006, 143, 397-406. [CrossRef] [PubMed]

24. Bian, R.; Chen, D.; Liu, X.; Cui, L.; Li, L.; Pan, G.; Xie, D.; Zheng, J.W.; Zhang, X.H.; Zheng, J.F.; et al. Biochar soil amendment as a solution to prevent Cd-tainted rice from china: Results from a cross-site field experiment. Ecol. Eng. 2013, 58, 378-383. [CrossRef]

25. Spurgeon, D.J.; Stürzenbaum, S.R.; Svendsen, C.; Hankard, P.K.; Morgan, A.J.; Weeks, J.M.; Kille, P. Toxicological, cellular and gene expression responses in earthworms exposed to copper and cadmium. Comp. Biochem. Phys. C 2004, 138, 11-21. [CrossRef] [PubMed]

26. Cui, L.; Li, L.; Mail, A.Z.; Pan, G. Biochar amendment greatly reduces rice cd uptake in a contaminated paddy soil: A two-year field experiment. Bioresources 2011, 6, 2605-2618. [CrossRef]

27. Liang, X.; Han, J.; Xu, Y.; Sun, Y.; Wang, L.; Tan, X. In situ field-scale remediation of Cd polluted paddy soil using sepiolite and palygorskite. Geoderma 2014, 235-236, 9-18. [CrossRef]

28. Mahabadi, A.A.; Hajabbasi, M.A.; Khademi, H.; Kazemian, H. Soil cadmium stabilization using an iranian natural zeolite. Geoderma 2007, 137, 388-393. [CrossRef]

29. Najafi, S.; Jalali, M. Effects of organic acids on cadmium and copper sorption and desorption by two calcareous soils. Environ. Monit. Assess. 2015, 187, 1-10. [CrossRef] [PubMed]

30. Gilmour, C.C.; Riedel, G.S.; Riedel, G.; Kwon, S.; Landis, R.; Brown, S.S.; Menzie, C.A.; Ghosh, U. Activated carbon mitigates mercury and methylmercury bioavailability in contaminated sediments. Environ. Sci. Technol. 2013, 47, 13001-13011. [CrossRef] [PubMed]

31. Van Poucke, R.; Ainsworth, J.; Maeseele, M.; Ok, Y.S.; Meers, E.; Tack, F.M.G. Chemical stabilization of Cd-contaminated soil using biochar. Appl. Geochem. 2018, 88, 122-130. [CrossRef]

32. He, H.; Nfy, T.; Yao, A.; Qiu, R.; Li, W.C.; Ye, Z. Growth and cd uptake by rice (Oryza sativa) in acidic and Cd-contaminated paddy soils amended with steel slag. Chemosphere 2017, 189, 247-254. [CrossRef] [PubMed] 
33. Li, S.; Wang, M.; Zhao, Z.; Li, X.; Han, Y.; Chen, S. Alleviation of cadmium phytotoxicity to wheat is associated with cd re-distribution in soil aggregates as affected by amendments. RSC Adv. 2018, 8, 17426-17434. [CrossRef]

34. Castaldi, P.; Santona, L.; Enzo, S.; Melis, P. Sorption processes and xrd analysis of a natural zeolite exchanged with $\mathrm{Pb}\left({ }^{2+}\right), \mathrm{Cd}\left({ }^{2+}\right)$ and $\mathrm{Zn}\left({ }^{2+}\right)$ cations. J. Hazard. Mater. 2008, 156, 428-434. [CrossRef] [PubMed]

35. Zama, E.F.; Zhu, Y.G.; Reid, B.J.; Sun, G.X. The role of biochar properties in influencing the sorption and desorption of $\mathrm{Pb}(\mathrm{II}), \mathrm{Cd}(\mathrm{II})$ and $\mathrm{As}(\mathrm{III})$ in aqueous solution. J. Clean. Prod. 2017, 148, 127-136. [CrossRef]

36. Ren, X.; Shao, D.; Yang, S.; Hu, J.; Sheng, G.; Tan, X.; Wang, X.K. Comparative study of Pb(II) sorption on XC-72 carbon and multi-walled carbon nanotubes from aqueous solutions. Chem. Eng. J. 2011, 170, 170-177. [CrossRef]

37. Chang, M.Y.; Juang, R.S. Adsorption of tannic acid, humic acid, and dyes from water using the composite of chitosan and activated clay. J. Colloid Interface Sci. 2004, 278, 18-25. [CrossRef] [PubMed]

38. da Silva, L.C.C.; dos Santos, L.B.O.; Abate, G.; Cosentino, I.C.; Fantini, M.C.A.; Masini, J.C.; Matos, J.R. Adsorption of $\mathrm{Pb}^{2+}, \mathrm{Cu}^{2+}$, and $\mathrm{Cd}^{2+}$, in FDU-1 silica and FDU-1 silica modified with humic acid. Micropor. Mesopor. Mat. 2008, 110, 250-259. [CrossRef]

39. Yan, G.Y.; Viraraghavan, T. Heavy-metal removal from aqueous solutionby fungus Mucor rouxii. Water Res. 2003, 37, 4486-4496. [CrossRef]

40. Tabaraki, R.; Ahmady-Asbchin, S.; Abdi, O. Biosorption of Zn(II) from aqueous solutions by Acinetobacter sp. isolated from petroleum spilled soil. J. Environ. Chem. Eng. 2013, 1, 604-608. [CrossRef]

41. Bian, R.; Joseph, S.; Cui, L.; Pan, G.; Li, L.; Liu, X.; Zhang, A.; Rutidge, H.; Wong, S.; Chia, C.; et al. A three-year experiment confirms continuous immobilization of cadmium and lead in contaminated paddy field with biochar amendment. J. Hazard. Mater. 2014, 272, 121-128. [CrossRef] [PubMed]

42. Li, X.; Liu, S.; Na, Z.; Lu, D.; Liu, Z. Adsorption, concentration, and recovery of aqueous heavy metal ions with the root powder of Eichhornia crassipes. Ecol. Eng. 2013, 60, 160-166. [CrossRef]

43. Khan, S.; Chao, C.; Waqas, M.; Arp, H.P.; Zhu, Y.G. Sewage sludge biochar influence upon rice (Oryza sativa) yield, metal bioaccumulation and greenhouse gas emissions from acidic paddy soil. Environ. Sci. Technol. 2013, 47, 8624-8632. [CrossRef] [PubMed]

44. Chen, T.; Zhou, Z.; Han, R.; Meng, R.; Wang, H.; Lu, W. Adsorption of cadmium by biochar derived from municipal sewage sludge: Impact factors and adsorption mechanism. Chemosphere 2015, 134, $286-293$. [CrossRef] [PubMed]

45. Ali, S.B.; Jaouali, I.; Souissi-Najar, S.; Ouederni, A. Characterization and adsorption capacity of raw pomegranate peel biosorbent for copper removal. J. Clean. Prod. 2016, 142, 3809-3821. [CrossRef]

46. Xu, Y.; Liang, X.F.; Xu, Y.M.; Qin, X.; Huang, Q.Q.; Wang, L.; Sun, Y.B. Remediation of Heavy Metal-Polluted Agricultural Soils Using Clay Minerals: A Review. Pedosphere 2017, 27, 193-204. [CrossRef]

47. Uddin, M.K. A review on the adsorption of heavy metals by clay minerals, with special focus on the past decade. Chem. Eng. J. 2017, 308, 438-462. [CrossRef]

48. Meitei, M.D.; Prasad, M.N.V. Lead(II) and cadmium(II) biosorption on Spirodela polyrhiza, (L.) schleiden biomass. J. Environ. Chem. Eng. 2013, 1, 200-207. [CrossRef]

49. Anirudhan, T.S.; Suchithra, P.S. Heavy metals uptake from aqueous solutions and industrial wastewaters by humic acid-immobilized polymer/bentonite composite: Kinetics and equilibrium modeling. Chem. Eng. J. 2010, 156, 146-156. [CrossRef]

50. Horká, M.; Rُ̊̌žčka, F.; Holá, V.; Šlais, K. Capillary isoelectric focusing of microorganisms in the pH range 2-5 in a dynamically modified FS capillary with UV detection. Anal. Bioanal. Chem. 2006, 385, 840-846. [CrossRef] [PubMed]

51. Martinsa, R.J.E.; Pardob, R.; Boaventura, R.A.R. Cadmium(II) and zinc(II) adsorption by the aquatic moss Fontinalis antipyretica: Effect of temperature, $\mathrm{pH}$ and water hardness. Water Res. 2004, 38, 693-699. [CrossRef] [PubMed]

52. Wang, L.; Meng, J.; Li, Z.T.; Liu, X.M.; Xia, F.; Xu, J.M. First “charosphere" view towards the transport and transformation of Cd with addition of manure derived biochar. Environ. Poll. 2017, 227, 175-182. [CrossRef] [PubMed]

53. Wang, T.; Liu, W.; Xiong, L.; Xu, N.; Ni, J.R. Influence of $\mathrm{pH}$, ionic strength and humic acid on competitive adsorption of $\mathrm{Pb}(\mathrm{II}), \mathrm{Cd}(\mathrm{II})$ and $\mathrm{Cr}(\mathrm{III})$ onto titanate nanotubes. Chem. Eng. J. 2013, 215-216, 366-374. [CrossRef] 
54. Zhu, Q.; Vries, W.D.; Liu, X.; Zeng, M.; Hao, T.; Du, E.; Zhang, F.; Shen, J. The contribution of atmospheric deposition and forest harvesting to forest soil acidification in china since 1980. Atmos. Environ. 2016, 146, 215-222. [CrossRef]

55. Jia, W.L.; Wang, B.L.; Wang, C.P.; Sun, H.W. Tourmaline and biochar for the remediation of acid soil polluted with heavy metals. J. Environ. Chem. Eng. 2017, 5, 2107-2114. [CrossRef]

56. Ledin, M.; Pedersen, K.; Allard, B. Effects of pH, ionic strength on the adsorption of Cs, Sr, Eu, Zn, Cd and $\mathrm{Hg}$ by pseudomonas putida. Water Air Soil Poll. 1997, 93, 367-381. [CrossRef]

(C) 2018 by the authors. Licensee MDPI, Basel, Switzerland. This article is an open access article distributed under the terms and conditions of the Creative Commons Attribution (CC BY) license (http:/ / creativecommons.org/licenses/by/4.0/). 